\title{
Medicinal trees from home gardens of urban areas in Madurai District of Tamil Nadu, Southern India
}

\author{
S. SHANMUGAM", G. JEYAPRABAKARAN, K. RAJENDRAN \\ Post Graduate and Research Department of Botany, Thiagarajar College. 139-140, Kamarajar Road, Teppakulam, Madurai 625009, Tamil Nadu, India, \\ vemail: shanmugambotany@gmail.com
}

Manuscript received: 1 March 2020. Revision accepted: 25 April 2020.

\begin{abstract}
Shanmugam S, Jeyaprabakaran G, Rajendran K. 2020. Medicinal trees from home gardens of urban areas in Madurai District of Tamil Nadu, Southern India. Asian J Ethnobiol 3: 10-15. Home gardens provide a diverse and stable supply of socioeconomic products. They serve as conservation spots of many valuable and rare medicinal plants. Present research work aims to elucidate the medicinally important trees growing in home gardens and their role in the health care of the inhabitants living in four urban areas of Madurai District, Tamil Nadu, India. Data was collected by interviewing 20 informants (14 male and 6 female) regarding the ethnomedicinal uses of plants prescribed to treat several ailments in total. We recorded 63 medicinal remedies prepared from 54 tree species belonging to 52 genera and 27 families to treat 35 illnesses. It was found that the most dominant family was Apocynaceae (5 species). Leaf was the most used plant part (28.56\%), and using raw material (20.64\%) was the most way to treat a particular disease. Phytochemical and pharmacological values of these medicinally essential trees should be tested. Awareness programs should also encourage people to grow many more valuable plants in their home gardens.
\end{abstract}

Keywords: Home gardens, Madurai urban, Medicinal trees, Tamil Nadu

\section{INTRODUCTION}

Home gardens are traditional agroforestry systems characterized by the complexity of their structure and multiple functions. Home gardens can be defined as land use systems involving deliberate management of multipurpose trees and shrubs in intimate association with annual and perennial crops and invariably livestock within the compounds of individual houses, the whole tree-crop animal unit being intensively managed by family labor (Fernandes and Nair 1986).

Home gardens have attracted considerable research attention during the past three decades mainly due to the following reasons: (i) they contain characteristics that make them an exciting model for research and the design of sustainable agroecosystems, including efficient nutrient cycling, high biodiversity, low use of external inputs and soil conservation potential; and (ii) home gardens have been shown to provide a diverse and stable supply of socioeconomic products and benefits to the families that maintain them (Jose and Shanmugaratnam 1993).

Home gardens are important in situ conservation sites. According to the Convention of Biological Diversity Article 7,8 and 10(c), inventory of such areas can help identify and conserve biodiversity while assessing the system's sustainability (Jose and Shanmugaratnam 1993). To understand the structure and function of home gardens, it is necessary to analyze both socio-economic and biophysical aspects of these systems.

The rapid disappearance of some wonderful medicinal plants due to over-exploitation and continuous extraction has led to the urgent need to protect such medicinal plants
(Jain 1976). In the last few decades, several factors, including population growth, expansion of large urban areas, construction activities such as dams, building, roads, encroachments on vast areas of forest land, shifting cultivation, mining operations, and industrialization, have been affected depleted robust ancient medicinal plants.

At the same time, home gardens located in urban areas of large cities, like in Madurai District, Tamil Nadu, India, serve as conservation spots of many valuable and rare medicinal plants. They are to be growing by the homeowners inside/outside of their residential areas. However, there was no detailed study about medicinal trees present in urban areas of Madurai District. Having these facts in mind, the current research work was carried out to explore the medicinal trees growing in home gardens in urban areas of Madurai District.

\section{MATERIALS AND METHODS}

\section{Study area}

The present study was conducted in four urban areas, i.e., Teppakulam, Anna Nagar, K.K. Nagar and Anupanadi of Madurai District in Tamil Nadu, India. Geographically, the entire area of Madurai District lies between $9^{\circ} 39^{\prime}-10^{\circ}$ $30^{\prime} \mathrm{N}$ latitude and $77^{\circ} 00^{\prime}-78^{\circ} 30^{\prime} \mathrm{E}$ longitude. The district is spread over about $6500 \mathrm{sq}$. $\mathrm{km}$, bounded on the north and northeast by Pudukkottai District, on the south by Virudhunagar District, and on the southwest by Theni District, on the west by Dindigul District, and the east by Sivagangai District. The district receives an annual rainfall 
of about $600-850 \mathrm{~mm}$ with temperature varies between $18^{\circ}$ and $40^{\circ} \mathrm{C}$.

\section{Field study}

An extensive survey was carried out in the urban areas of Madurai District for 6 months period, from July December 2019. The known and familiar plants were recorded on the spot, while the unknown and doubtful plants were collected and brought to the laboratory for identification. All the plants were botanically identified with the help of Flora of Tamil Nadu Carnatic (Matthew 1983) and An Excursion Flora of Central Tamil Nadu (Matthew 1991).

\section{Data collection}

Informants were interviewed individually in the local language (Tamil). Semi-structured interviews addressed questions regarding medicinal data on trees. Its uses included local plant name, name of disease treated, plant parts used, other parts or herbs used along with (if any), methods of remedy preparation, and mode of administration (Cotton 1996). The Prior Informed Consent (PIC) was obtained verbally before commencing each interview. The total number of informants involved in the ethnomedicinal survey was 20 (14 male and 6 female). The age of the individuals ranged from 30 to 95 years. Answers of respondents were translated into English and noted down by the interviewers.

\section{RESULTS AND DISCUSSION}

\section{Diversity of medicinal trees}

A total of 54 tree species belonging to 52 genera distributed among 27 families were recorded. The list of the plants recorded in the study area with their family name, local name, and uses are presented in Table 1. Among 54 species, dicotyledons were represented by 47 species of 49 genera belonging to 25 families, and monocotyledons were 5 species of 5 genera belonging to 2 families (Table 2).
Among the 27 families listed, Apocynaceae was the most dominant family comprising 5 species from 4 genera. Arecaceae, Caesalpiniaceae, and Fabaceae shared the second largest family represented by 4 species each. The third-largest families were Meliaceae, Moraceae, Rubiaceae, and Sapindaceae; all were represented by 3 species, followed by Annonaceae, Euphorbiaceae, Mimosaceae, Myrtaceae, and Verbenaceae (2 species of each). The rest of the 13 families were represented by single species only (Table 2). Among the genus of the medicinal trees reported, Phyllanthus of Euphorbiaceae and Plumeria of Apocynaceae were represented by 2 species that were the dominant genus (Table 1).

\section{Quantitative ethnomedicinal analyses}

During the present investigation, the informants in the study area prepared 63 medicinal remedies from 54 plants used to treat 35 different illnesses (Table 3). The plants obtained were fully grown in the home gardens of the urban areas of Madurai District.

\section{Plant parts used}

Regarding the plant parts used, it was observed that leaf is the most used plant part $(28.56 \%)$ to treat a particular disease followed by stem bark and fruit (19.05\% of each), stem $(6.35 \%)$, root $(6.34 \%)$, seed $(4.77 \%)$, flower $(4.76 \%)$, fruit pulp $(4.76 \%)$ and root bark $(3.18 \%)$. Corm and seed coat is the least used part (each $1.59 \%$ ) (Table 4). Most of the earlier ethnobotanical studies confirmed that leaves are the central portion of the plant used in the treatment of diseases (Arinathan et al. 2003; Subramanian et al. 2003; Ayyanar et al. 2008; Ignacimuthu et al. 2008; Mohan et al. 2008; Rajendran et al. 2008; Shanmugam et al. 2007; 2008; Alagesaboopathi 2011; 2012; Shanmugam et al. 2011a, b; 2012; Alagesaboopathi et al. 2018).

The reasons behind the extensive use of leaves are probably attributable to their easy availability throughout the year. Leaves were active in photosynthesis, where the production and storage of secondary metabolites, which are responsible for the remedy of a particular ailment, is in high concentration compared to other parts of the plants (Ayyanar and Ignacimuthu 2005; Shanmugam et al. 2007).

Table 1. List of medicinally important trees present in home gardens of Madurai District, Tamil Nadu, Southern India, with their family name, local name, and medicinal uses

\begin{tabular}{|c|c|c|c|}
\hline Botanical name & Family name & Local name & Medicinal use(s) \\
\hline Achras zapota $\mathrm{L}$. & Sapotaceae & Sappottaa & Fruits are eaten raw for stomach ulcers. \\
\hline Aegle marmelos (L.) Corr. Serr. & Rutaceae & Vilvam & $\begin{array}{l}\text { Stem bark powder is boiled with goat milk and filtered. } \\
\text { This liquid is taken orally two times for three days to } \\
\text { relieve stomach pain during menstruation. The fruit pulp is } \\
\text { mixed with honey and eaten to reduce body heat. }\end{array}$ \\
\hline Ailanthus excelsa Roxb. & Simaroubaceae & $\begin{array}{l}\text { Theekuchi } \\
\text { maram }\end{array}$ & Root bark decoction is recommended for asthma. \\
\hline Albizia lebbeck (L.) Benth. & Mimosaceae & Vaagai & Leaf paste is applied for eczema. \\
\hline Alstonia scholaris (L.) R.Br. & Apocynaceae & Yealilaippaalai & Stem latex is applied to the wound. \\
\hline Annona squamosa $\mathrm{L}$. & Annonaceae & Seethaapazham & Fruit powder with pepper powder is used to cure fever. \\
\hline
\end{tabular}




\begin{tabular}{|c|c|c|c|}
\hline Anthocephalus cadamba Miq. & Rubiaceae & Kadambam & $\begin{array}{l}\text { Stem bark juice with common salt is prescribed for eye } \\
\text { inflammation. }\end{array}$ \\
\hline Areca catech $\mathrm{L}$. & Arecaceae & Paakku & Seed is eaten raw to improve digestion. \\
\hline Artocarpus heterophyllus Lam. & Moraceae & Palaa & Fruit pulp is eaten for anemia. \\
\hline Azadirachta indica Adr. Juss. & Meliaceae & Vaembu & $\begin{array}{l}\text { Stem bark paste is applied for skin eruption. Leaf decoction } \\
\text { is taken orally for ulcers. }\end{array}$ \\
\hline Bauhinia purpurea $\mathrm{L}$. & Caesalpiniaceae & Mandhaarai & Root bark paste is applied for boils. \\
\hline Bombax ceiba $\mathrm{L}$. & Bombacaceae & Yilavam & Stem exudate is given for diarrhea and dysentery. \\
\hline Carica papaya $\mathrm{L}$. & Caricaceae & Pappaali & $\begin{array}{l}\text { Milky latex of fruit is applied to teeth to relieve } \\
\text { toothache. }\end{array}$ \\
\hline Caryota urens $\mathrm{L}$. & Arecaceae & Koondhalpanai & Leaf ash is used for inflammation. \\
\hline $\begin{array}{l}\text { Casuarina equisetifolia Forster \& } \\
\text { Forster }\end{array}$ & Casuarinaceae & Savukku & Decoction of leaves is used to cure fever. \\
\hline Citrus medica $\mathrm{L}$. & Rutaceae & Yelumichai & $\begin{array}{l}\text { Fruit juice mixed with milk is taken two times a day for } \\
\text { dysentery. }\end{array}$ \\
\hline Cocos nucifera $\mathrm{L}$. & Arecaceae & Thennai & Fruit endosperm is eaten raw for dysentery. \\
\hline Crateva religiosa auct. non-Forster & Capparidaceae & Maavilangam & Stem bark extract is used to enhance eat appetite. \\
\hline Dalbergia sissoo Roxb. & Fabaceae & Yeetti & $\begin{array}{l}\text { Stem bark paste is mixed with pepper paste and taken } \\
\text { orally for fever. }\end{array}$ \\
\hline Delonix regia (Hook.f.) Raf. & Caesalpiniaceae & $\begin{array}{l}\text { Kaattuthee } \\
\text { maram }\end{array}$ & Leaf paste is applied for skin dryness. \\
\hline Erythrina suberosa Roxb. & Fabaceae & Mullmurungai & Leaves are cooked and eaten for cold and cough. \\
\hline Eucalyptus globulus Labill. & Myrtaceae & Thailamaram & $\begin{array}{l}\text { Leaves are boiled, and the vapor is inhaled for cold and } \\
\text { cough. }\end{array}$ \\
\hline Ficus religiosa $\mathrm{L}$. & Moraceae & trac & Stem bark decoction is used for jaundice. \\
\hline Gmelina arborea $\mathrm{L}$. & Verbenaceae & $\mathrm{zh}$ & Root decoction is used in rheum \\
\hline Lawsonia inermis $\mathrm{L}$. & Lythraceae & Tarudhaani & Leaf paste is applied for cracks on foot. \\
\hline Madhuca indica J. F. Gmel. & Sapotaceae & Yiluppai & Seed decoction is taken orally for rheumatism. \\
\hline Mangifera indica $\mathrm{L}$. & Anacardiaceae & Maamaram & $\begin{array}{l}\text { Stem bark paste is applied for hemorrhage. Latex obtained } \\
\text { from the stem is used to the wound. }\end{array}$ \\
\hline Melia azedarach $\mathrm{L}$. & Mel & Mal & Juice of stem bark is taken internally for stomach pain. \\
\hline Millingtonia hortensis L.f. & Bignoniaceae & am & Flower juice is applied to the wound. \\
\hline Mimusops elengi $\mathrm{L}$. & Sapotaceae & Makizham & Fruit juice is used for diarrhea and dysentery. \\
\hline Morinda tinctoria Roxb. & Rubiaceae & Manjanathi & Leaf extract is taken orally to cure dysentery. \\
\hline Moringa oleifera Lam. & Moringaceae & Murungai & $\begin{array}{l}\text { Cooked leaves are eaten to increase fertility in men. Stem } \\
\text { bark juice is used to cure stomach pain. }\end{array}$ \\
\hline Morus alba L. & Moraceae & Musukkottai & Fruit is eaten raw for sore throat. \\
\hline Musa paradisiaca $\mathrm{L}$. & Musaceae & Vaazhai & $\begin{array}{l}\text { Corm extract is given for snake bites. Fruit is eaten raw for } \\
\text { intestinal worms. }\end{array}$ \\
\hline Parkinsonia aculeata $\mathrm{L}$. & Caesalpiniaceae & $\begin{array}{l}\text { Sudukaatu } \\
\text { maram }\end{array}$ & Stem bark decoction is taken orally to cure dysentery. \\
\hline Phoenix sylvestris (L.) Roxb. & t & am & is preccribed for indirection \\
\hline Phyllanthus acidus (L.) Skeels & Euphorbiaceae & Sirunelli & aten raw for body heat. \\
\hline Phyllanthus emblica L. & Euphorbiaceae & Nelli & Fruits are eaten raw to cure anemia. \\
\hline Pithecellobium dulce (Roxb.) Benth. & Mimosaceae & Kodukkaap & $\begin{array}{l}\text { Leaf juice is mixed with onion juice and applied for hair } \\
\text { growth. }\end{array}$ \\
\hline Plumeria alba $\mathrm{L}$. & Apoc & 10 & Latex is applied to the wounds. \\
\hline Plumeria rubra $\mathrm{L}$. & Apocynaceae & Yeelathalari & Flower paste is applied to the wound. \\
\hline $\begin{array}{l}\text { Polyalthia longifolia (Sonn.) } \\
\text { Thwaites }\end{array}$ & Annonaceae & Nettilingam & Root decoction is used for fever. \\
\hline Pongamia glabra Vent. & Fabaceae & Pungam & $\begin{array}{l}\text { Juice of leaves is prescribed for diarrhea. Root juice is used } \\
\text { for ulcers. Fresh stem bark is given to chew for piles. }\end{array}$ \\
\hline ajava $\mathrm{L}$. & My & $T=0$ & Stem \\
\hline Sapindus emarginatus Vahl & Sapindacea & hikkottai & lly for asthma. \\
\hline Sesbania grandifolia (L.) Poiret & Fabaceae & gathi & Leaves are cooked and eaten for stomach ulcers. \\
\hline Swietenia mahagoni (L.) Jacq. & Meliaceae & Makhaagani & Leaf extract is given to drink for diabetes. \\
\hline Syzygium cumini (L.) Skeels & Myrtaceae & Naaval & Seed powder is used for diabetes. \\
\hline Tamarindus indica $\mathrm{L}$. & Caesalpiniaceae & Puli & $\begin{array}{l}\text { Seed coat paste is applied on the spot of scorpion bite to } \\
\text { relieve pain. }\end{array}$ \\
\hline Tectona grandis L.f. & Verbenaceae & Thaekku & $\begin{array}{l}\text { Flower juice is used in urinary pain. Stem bark paste is } \\
\text { used in bronchitis. }\end{array}$ \\
\hline Thevetia peruviana $\mathrm{L}$. & Apocynaceae & Visha arali & $\begin{array}{l}\text { Latex obtained from leaves is diluted and taken internally } \\
\text { for white discharge. }\end{array}$ \\
\hline Thespesia populnea $\mathrm{L}$. & Malv & roovarasu & Leaf paste is applied for leprosy. \\
\hline Wrightia tinctoria (Roxb.) R.Br. & naceae & Paalai & Leaf paste mixed with neem oil is applied for eczema. \\
\hline $\begin{array}{l}\text { Ziziphus jujuba (L.) Gaertner, } \\
\text { non Miller }\end{array}$ & Rhamnaceae & Yilandhai & $\begin{array}{l}\text { Dried leaves are burnt, and the smoke is inhaled for cold } \\
\text { and cough. Fruits are eaten raw for stomachache. }\end{array}$ \\
\hline
\end{tabular}


Table 2. List families with several genera and species

\begin{tabular}{lcc}
\hline Family & Number of genus & Number of species \\
\hline Anacardiaceae & 1 & 1 \\
Annonaceae & 2 & 2 \\
Apocynaceae & 4 & 5 \\
Arecaceae $^{\dagger}$ & 4 & 4 \\
Bignoniaceae $_{\text {Bombacaceae }}$ & 1 & 1 \\
Caesalpiniaceae & 1 & 1 \\
Capparidaceae & 4 & 4 \\
Caricaceae & 1 & 1 \\
Casuarinaceae & 1 & 1 \\
Euphorbiaceae & 1 & 1 \\
Fabaceae & 1 & 2 \\
Lythraceae & 4 & 4 \\
Malvaceae & 1 & 1 \\
Meliaceae & 1 & 1 \\
Mimosaceae & 3 & 3 \\
Moraceae & 2 & 2 \\
Moringaceae & 3 & 3 \\
Musaceae & 1 & 1 \\
Myrtaceae & 1 & 1 \\
Rhamnaceae & 2 & 2 \\
Rubiaceae & 1 & 1 \\
Rutaceae & 3 & 3 \\
Sapindaceae & 2 & 2 \\
Sapotaceae & 1 & 1 \\
Simaroubaceae & 3 & 3 \\
Verbenaceae & 1 & 1 \\
\hline Note ${ }^{\dagger}$ (a) & 2 & 2 \\
\hline
\end{tabular}

Note: ${ }^{\dagger}$ Monocot families: others are dicots

\section{Medical preparations and their admission}

The medical remedies followed by the local inhabitants of Madurai urban to cure disease were based on many kinds of preparations which are as follows. Ash - the plant material is burnt and then powdered. This powder is used as ash for medicinal preparation. Cooked - the plant material is cooked and eaten with a regular diet. Decoction - a decoction is obtained by boiling the plant in water until the volume of liquid is reduced to more than $1 / 2$ or $3 / 4$ of the original amount of liquid. Extract - the plant material is grind with action water as needed and filtered. The filtrate is used as an extract. Exudate - the plant's stem portion is scratched out using sharp tools like a knife, and the outcome fluid is used for medicine as exudate. Juice - the juice is obtained by grinding the plant material, and this preparation was administered wholly (not filtered). Latex latex is obtained by detaching the leaf or young stem at the nodal region of the plant and used. Paste - the paste is prepared by grinding fresh or dried material with water. Powder - the powder is prepared by grinding dried material. Raw - the plant material is also used in natural form, was used immediately after harvesting. Vapor - the fresh plant material is boiled, and the fume generated from it is inhaled.

From the present research work, it was also noted that the local people living in Madurai urban used the medicinal preparation mainly in the form of raw $(20.64 \%)$, followed by paste $(17.46 \%)$, juice $(15.56 \%)$, decoction $(14.29 \%)$, latex $(7.94 \%)$, extract $(6.35 \%)$, cooked $(6.34 \%)$, powder $(4.77 \%)$ and vapor $(3.17 \%)$. Some medicines were also used in ash form (1.59\%) and exudate (1.59\%) (Table 4). Such a wide array of preparations was also reported by various studies carried out in different regions of Tamil Nadu like Theni district (Ignacimuthu et al. 2008), Shenbagathope (Shanmugam et al. 2008), Pachalur (Shanmugam et al. 2011a), Sivagangai district (Shanmugam et al. 2011b; 2012), Red Hills (Francisca and Rajendran 2012), Yercaud hills (Parthipan et al. 2017), etc.

\section{Medicinal species with great use versatility}

The present study showed that the local inhabitants used many collected plants to treat multiple diseases. Pongamia glabra (diarrhea, piles, and ulcer) and Ziziphus jujuba (cold, cough, and stomach-ache) are used for the treatment of these three diseases; Aegle marmelos (menstrual pain and body heat), Azadirachta indica (skin eruption and ulcer), Bombax ceiba (diarrhea and dysentery), Erythrina suberosa (cold and cough), Eucalyptus globulus (cold and cough), Mangifera indica (hemorrhage and wound), Mimusops elengi (diarrhea and dysentery), Moringa oleifera (male infertility and stomach pain), Musa paradisiaca (snake bite and intestinal worms) and Tectona grandis (urinary pain and bronchitis) were used for two diseases. The rest of the plants treat only one disease (Table 1).

\section{Extensively used plants for illness}

The local people of the study area used the herbal preparations made from the traditional medicinal plants used primarily for the treatment of dysentery (6 species: Bombax ceiba, Citrus medica, Cocos nucifera, Mimusops elengi, Morinda tinctoria, and Parkinsonia aculeata), wound (5 species: Alstonia scholaris, Mangifera indica, Millingtonia hortensis, Plumeria alba and Plumeria Rubra), diarrhea (4 species: Bombax ceiba, Mimusops elengi, Pongamia glabra and Psidium guajava), fever (4 species: Annona squamosa, Casuarina equisetifolia, Dalbergia sissoo, and Polyalthia longifolia), ulcer (4 species: Achras zapota, Azadirachta indica, Pongamia glabra, and Sesbania grandifolia), cold (3 species: Erythrina suberosa, Eucalyptus globulus, and Ziziphus jujuba), cough (3 species: Erythrina suberosa, Eucalyptus globulus, and Ziziphus jujuba) and stomach pain (3 species: Melia azedarach, Moringa oleifera and Ziziphus jujuba) (Table 3). Use of medicines with ingredients

Generally, the informants used a medicinal preparation made from a plant alone to treat a disease. In some cases, they used medicinal preparation, other plant products, and other substances like milk or honey to cure a particular illness. For example, stem bark powder of Aegle marmelos is boiled with goat milk, and this liquid is taken orally, two times for three days to get relief from stomach pain during menstruation; fruit pulp of Aegle marmelos is mixed with honey and eaten to reduce body heat, fruit juice of Citrus medica with milk is taken two times a day for dysentery, leaf paste of Wrightia tinctoria mixed with neem oil, is applied for eczema and stem bark paste of Dalbergia sissoo is mixed with pepper paste and taken orally for fever (Table 1) 
Table 3. List of illness, number of remedies, and name of the plants used by the informants of the study area in Madurai District, Tamil Nadu, Southern India

\begin{tabular}{|c|c|c|}
\hline $\begin{array}{l}\text { Name of the } \\
\text { illness }\end{array}$ & $\begin{array}{l}\text { Number of } \\
\text { remedies used }\end{array}$ & Botanical name of the plants used \\
\hline Anemia & 2 & Artocarpus heterophyllus and Phyllanthus emblica \\
\hline Appetite & 1 & Crateva religiosa \\
\hline Asthma & 2 & Ailanthus excelsa and Sapindus emarginatus \\
\hline Body heat & 2 & Aegle marmelos and Phyllanthus acidus \\
\hline Boils & 1 & Bauhinia purpurea \\
\hline Bronchitis & 1 & Tectona grandis \\
\hline Cold & 3 & Erythrina suberosa, Eucalyptus globulus and Ziziphus jujuba \\
\hline Cough & 3 & Erythrina suberosa, Eucalyptus globulus and Ziziphus jujuba \\
\hline Crack & 1 & Lawsonia inermis \\
\hline Diabetes & 2 & Swietenia mahagoni and Syzygium cumini \\
\hline Diarrhea & 4 & Bombax ceiba, Mimusops elengi, Pongamia glabra and Psidium guajava \\
\hline Dysentery & 6 & $\begin{array}{l}\text { Bombax ceiba, Citrus medica, Cocos nucifera, Mimusops elengi, Morinda tinctoria and } \\
\text { Parkinsonia aculeata }\end{array}$ \\
\hline Eczema & 2 & Albizia lebbeck and Wrightia tinctoria \\
\hline Fever & 4 & Annona squamosa, Casuarina equisetifolia, Dalbergia sissoo and Polyalthia longifolia \\
\hline Hemorrhage & 1 & Mangifera indica \\
\hline Hair growth & 1 & Pithecellobium dulce \\
\hline Indigestion & 2 & Areca catechu and Phoenix sylvestris \\
\hline Inflammation & 1 & Anthocephalus cadamba and Caryota urens \\
\hline Intestinal worms & 1 & Musa paradisiaca \\
\hline Jaundice & 1 & Ficus religiosa \\
\hline Leprosy & 1 & Thespesia populnea \\
\hline Male infertility & 1 & Moringa oleifera \\
\hline Menstrual pain & 1 & Aegle marmelos \\
\hline Piles & 1 & Pongamia glabra \\
\hline Rheumatism & 2 & Gmelina arborea and Madhuca indica \\
\hline Scorpion sting & 1 & Tamarindus indica \\
\hline Skin dryness & 1 & Delonix regia \\
\hline Snake bite & 1 & Musa paradisiaca \\
\hline Sore throat & 1 & Morus alba \\
\hline Stomach pain & 3 & Melia azedarach, Moringa oleifera and Ziziphus jujuba \\
\hline Stomach ulcer & 4 & Achras zapota, Azadirachta indica, Pongamia glabra and Sesbania grandifolia \\
\hline Tooth-ache & 1 & Carica papaya \\
\hline Urinary pain & 1 & Tectona grandis \\
\hline White discharge & 1 & Thevetia peruviana \\
\hline Wound & 5 & $\begin{array}{l}\text { Alstonia scholaris, Mangifera indica, Millingtonia hortensis, Plumeria alba, and Plumeria } \\
\text { Rubra }\end{array}$ \\
\hline
\end{tabular}

Table 4. Percent distribution of parts used and mode of treatment followed by the informants of the study area in Madurai District, Tamil Nadu, Southern India

\begin{tabular}{|c|c|c|c|c|c|c|c|c|c|c|c|c|}
\hline \multirow{2}{*}{ Parts used } & \multicolumn{11}{|c|}{ Mode of treatment } & \multirow{2}{*}{$\begin{array}{c}\text { Total } \\
(\%)\end{array}$} \\
\hline & Ash & Cooked & Decoction & Extract & Exudate & Juice & Latex & Paste & Powder & Raw & Vapour & \\
\hline Corm & - & - & - & 1.59 & - & - & - & - & - & - & - & 1.59 \\
\hline Flower & - & - & - & - & - & 3.17 & - & 1.59 & - & - & - & 4.76 \\
\hline Fruit & - & - & 1.59 & - & - & 3.17 & 1.59 & - & 1.59 & 11.11 & - & 19.05 \\
\hline Fruit pulp & - & - & - & - & - & - & - & - & - & 4.76 & - & 4.76 \\
\hline Leaf & 1.59 & 6.34 & 1.59 & 3.17 & - & 1.59 & 1.59 & 7.93 & - & 1.59 & 3.17 & 28.56 \\
\hline Root & - & - & 3.17 & - & - & 3.17 & - & - & - & - & - & 6.34 \\
\hline Root bark & - & - & 1.59 & - & - & - & - & 1.59 & - & - & - & 3.18 \\
\hline Seed & - & - & 1.59 & - & - & - & - & - & 1.59 & 1.59 & - & 4.77 \\
\hline Seed coat & - & - & - & - & - & - & - & 1.59 & - & - & - & 1.59 \\
\hline Stem & - & - & - & - & 1.59 & - & 4.76 & - & - & - & - & 6.35 \\
\hline Stem bark & - & - & 4.76 & 1.59 & - & 4.76 & - & 4.76 & 1.59 & 1.59 & - & 19.05 \\
\hline Total (\%) & 1.59 & 6.34 & 14.29 & 6.35 & 1.59 & 15.86 & 7.94 & 17.46 & 4.77 & 20.64 & 3.17 & 100 \\
\hline
\end{tabular}


It is believed that a medicine prepared using multiple plant parts and other products like milk, honey contains a range of pharmacologically active compounds and has more healing power than single plant products (Teklehaymanot and Giday 2007).

In conclusion, the findings of this study may become bare leads for chemical, pharmacological, clinical, and biochemical investigations, which ultimately may lead to drug discovery. Therefore, these medicinally essential plants' phytochemical and pharmacological values should be tested. Further studies must be carried out to explore Madurai District's entire floral wealth of urban forestry. The best occurrence information we have suggests that large numbers of plant occurrences remain in urban areas of Madurai. Further, most species have at least one event on public lands. It appears plausible that the most vulnerable plant species can be preserved in natural environments, even within the urban context of Madurai. Otherwise, there may be a possibility of the extinction of that particular plant species.

Home gardens are essential sites for in situ conservation of plant diversity and serve as gene pools for eroding indigenous tree species. Many wild, rare tree species like Anthocephalus cadamba, Caryota urens, and Swietenia mahagoni are also conserved in home gardens because of their high commercial value. It is to be mentioned that the management of such trees in home gardens is often used as an indicator of social status among the local inhabitants. It was observed that there is an increasing interest in cultivating the plant among local inhabitants in the study area. Therefore, encouraging programs should be conducted to the homeowners to grow many more valuable plants in their home gardens and make them biodiversity conservation spots.

\section{ACKNOWLEDGEMENTS}

The authors are cordially grateful to the people inhabiting different localities of urban areas in Madurai District in Madurai District, Tamil Nadu, Southern India, because of their kind support and co-operation during the field trips.

\section{REFERENCES}

Alagesaboopathi C, Prabakaran G, Subramanian G, Vijayakumar RP 2018. Ethnomedicinal studies of plants growing in the Salem district of Tamil Nadu, India. Int J Pharma Biol Sci 8 (3): 503-511.

Alagesaboopathi C. 2011. Ethnobotanical studies on useful plants of Kanjamalai hills of Salem district of Tamil Nadu, Southern India. Arch Appl Sci Res 3: 532-539.
Alagesaboopathi C. 2012. Ethnobotanical survey of medicinal plants used by Malayalitribals and rural people in Salem district of Tamil Nadu, India. J Pharma Res 5 (12): 5248-5252.

Arinathan V, Mohan VR, John de Britto A, Chelladurai V. 2003. Studies on food and medicinal plants of Western Ghats. J Econ Taxon Bot 27: $750-753$.

Ayyanar M, Ignacimuthu S. 2005. Traditional knowledge of Kani tribals in Kouthalai of Tirunelveli hills, Tamil Nadu, India. J Ethnopharmacol 102: 246-255. DOI: 10.1016/j.jep.2005.06.020.

Ayyanar M, Sankarasivaraman K, Ignacimuthu S. 2008. Traditional herbal medicines used for the treatment of diabetes among two major tribal groups in South Tamil Nadu, India. Ethnobot Leafl 12: 276-280.

Cotton CM. 1996. Ethnobotany: Principles and Applications. John Wiley and Sons Ltd., New York.

Fernandes ECM, Nair PKR. 1986. An evaluation of the structure and function of tropical home gardens. Agricult Syst 21: 279-310. DOI: /10.1016/0308-521X(86)90104-6.

Francisca GB, Rajendran A. 2012. Ethnobotany of Irular tribes in Red hills, Tamil Nadu, India. Asian Pacific J Trop Dis S874-S877. DOI: 10.1016/S2222-1808(12)60283-7.

Ignacimuthu S, Ayyanar M, Sankarasivaraman K. 2008. Ethnobotanical study of medicinal plants used by Paliyar tribals in Theni district of Tamil Nadu, India. Fitoterapia 79: 562-568. DOI: 10.1016/j.fitote.2008.06.003.

Jain SK. 1976. A Handbook of Field and Herbarium Methods. Today and Tomorrow Printers and Publishers, New Delhi, India.

Jose D, Shanmugaratnam N. 1993. Traditional homegardens of Kerala: A sustainable human ecosystem. Agrofor Syst 24: 203-213. DOI: 10.1007/BF00706892.

Matthew KM. 1983. Flora of Tamil Nadu Carnatic. The Rapinat Herbarium, St. Joseph's College, Tiruchirapalli, Tamil Nadu, India.

Matthew KM. 1991. An Excursion Flora of Central Tamil Nadu. OxfordIBH Publishing Co. Pvt. Ltd., New Delhi, India.

Mohan VR, Rajesh A, Athiperumalsami T, Sutha S. 2008. Ethnomedicinal plants of the Tirunelveli district, Tamil Nadu, India. Ethnobot Leafl 12: 79-95.

Parthipan M, Aravindhan V, Rajendran A. 2017. Medico-botanical study of Yercaud hills in the Eastern Ghats of Tamil Nadu, India. Anc Sci Life 30: 104-109.

Rajendran K, Balaji P, Jothibasu M. 2008. Medicinal plants and their utilization by villagers in Southern districts of Tamil Nadu. Indian $\mathrm{J}$ Trad Knowl 7 (3): 417-420.

Shanmugam S, Annadurai M, Rajendran K. 2011a. Ethnomedicinal plants used to cure diarrhea and dysentery in Pachalur hills of Dindigul district in Tamil Nadu, Southern India. J Appl Pharmaceut Sci 1 (8): 94-97.

Shanmugam S, Kalaiselvan M, Selvakumar P, Suresh K, Rajendran K. 2011 b. Ethnomedicinal plants used to cure diarrhea and dysentery in Sivagangai district of Tamil Nadu, India. Int J Res Ayur Pharm 2 (5): 991-994.

Shanmugam S, Rajagopal V, Rajendran, K. 2007. Multipurpose usable plants in Thalaiyanai hills of Tirunelveli forest division in southern part of Western Ghats. J Non-Tim For Prod 14 (4): 297-306.

Shanmugam S, Rajendran K, Suresh K. 2012. Traditional uses of medicinal plants among the rural people in Sivagangai district of Tamil Nadu, Southern India. Asian Pacific J Trop Biomed 2 (1): S429-S434.10.1016/S2221-1691(12)60201-9.

Shanmugam S, Ramar S, Ragavendhar K, Ramanathan R, Rajendran K. 2008. Plants are used as medicine by Paliyar tribes of Shenbagathope in Virudhunagar district of Tamil Nadu. J Econ Taxon Bot 32 (4): 922-929.

Subramanian A, Mohan VR, Kumaresan S, Chelladurai V. 2003. Medicinal plants used by the valaiyans of Madurai District. Tamil Nadu. J Econ Taxon Bot 27: 785-787.

Teklehaymanot T, Giday, M. 2007. Ethnobotanical study of medicinal plants used by people in Zegie Peninsula, Northwestern Ethiopia. J Ethnobiol Ethnomed 3: 12. DOI: 10.1186/1746-4269-3-12. 